\title{
Caneberry Breeders in North America
}

\author{
Chad E. Finn ${ }^{1}$ \\ U.S. Department of Agriculture, Agricultural Research Service, 3420 N.W. Orchard Avenue, Corvallis, OR 97330
}

The breeding of caneberries (also referred to as brambles) has taken several directions in the last century. Red raspberries were of great interest throughout this time. Black raspberries received much more attention 50 to 75 years ago than they do today. Blackberries have gone from a crop that was largely in the realm of amateur breeders to a crop with several intensive breeding programs. Primocane raspberries, and now primocane blackberries, have revolutionized or will revolutionize their production and marketing. Breeders have played a critical role in these changes and in developing the caneberries as major commercial fruit crops. Many caneberry breeders have been instrumental, each in their own way, in moving the science and art of caneberry breeding forward.

Several breeders that have played small but critical roles in caneberry breeding and are more commonly remembered for their contribution in other fields will be mentioned first. George M. Darrow (1899-1983), while only dabbling in caneberries, provided the leadership at the national level for others who focused heavily on these fruit. He also is largely credited with getting the 'Merton Thornless' source of thornlessness into useful blackberry germplasm. James H. Logan (1841-1928), a California judge and hobbyist breeder, recognized the value of 'Logan' and made it available to the public at no cost, which was unusual for the time, thereby helping establish the northwestern U.S. processing industry. Byrnes M. Young (1858-1964), of Morgan City, La., originated the 'Young' dewberry (Youngberry), through which many red raspberry genes were brought into the blackberry germplasm pool. H. Ness, Sidney H. Yarnell (1898-1981), and H.F. Morris, from Texas, developed cultivars such as 'Nessberry' (a parent of the still popular 'Brazos'), which combined the trailing blackberry $R$. trivialis with red raspberry, that are adapted to warm climates with low chilling. Earl V. Goldsmith(1892-1954) and Stephen Whilhelm (1919-2002), with Sweetbriar Co. and Driscoll Strawberry Associates in Watsonville, Calif., are largely responsible for originally assembling the germplasm that has led to the most successful private raspberry breeding program in the world. Their vision for the type of plant needed for commercial production in California and for the type of fruit quality that was necessary for long distance shipping combined with their ability to incorporate germplasm from the U.K., Canada, and Sweden into the material they had available has led to the success of this program. Elwyn M. Meader(1910-1996) from the University of New Hampshire and Donald L. Craig (born in 1923) with Agriculture and Agri-Foods Canada, Nova Scotia, played crucial roles in the development of improved primocane

${ }^{1}$ Research geneticist; e-mail finnc@science.oregonstate.edu. fruiting raspberries. Meader and the scientists at the New York Agricultural Experiment Station were responsible for bringing primocane fruiting from a novelty to commercial cultivars. Craig helped this process and pushed it further with the development of improved cultivars for eastern North America.

This reminiscence will highlight seven breeders who have made outstanding contribution in the last half of the 20th century.

\section{GEORGE F. WALDO}

George Waldo (1898-1985) (Fig. 1), while born in 1898 in Drayton, N.Dak., spent most of his early years in Dayton, Ore. He earned his BS from Oregon State College in 1922 and his MS from Michigan State College in 1924. He went immediately to work for the U.S. Department of Agriculture-Agricultural Research Service(USDA-ARS) in Glenn Dale, $\mathrm{Md}$., where he was in charge of berry breeding from 1926-1932. In 1932, he and George Darrow, who was working as the berry breeder for the USDA-ARS in Oregon, swapped positions. This seemed to suit them both very well as Waldo was a reserved person who really didn't seem to have the personality to lead a far flung group of scientists in a national breeding effort. While Waldo developed a very successful strawberry program, he made his greatest mark in caneberries. When he returned to the Northwest from Maryland, the industry was primarily reliant on eastern raspberries, 'Logan', and hermaphroditic selections of the wild Rubus ursinus. By and large he is responsible for the development of the trailing blackberry germplasm that the industry worldwide is dependent on and his 'Marion' blackberry (marionberry) is the most widely grown cultivar in the world.

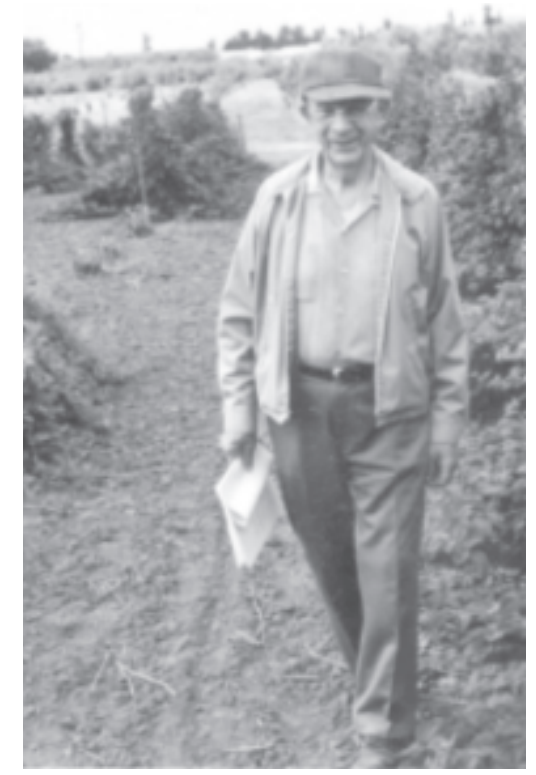

Fig. 1. George Waldo.
One of the reasons he seemed to have success is that in the high ploidy level Rubus germplasm he "knew no boundaries as what could be put together" (F.J. Lawrence). According to Lawrence, while Royce Bringhurst told him that "it's not possible to make such crosses," he didn't follow the rules on blackberry. Waldo was passionate about flavor and didn't think highly of Darrow's love of very acidic flavors. Apparently Darrow's love of acidic fruit was somewhat extreme, as his brother said to J. Moore "George was shortchanged at birth for stomach acid and he's been making up for it ever since." Waldo also had a great impact in the raspberries with the release of 'Willamette', which may be the most widely grown raspberry in the world. 'Willamette's adaptability and immunity to raspberry bushy dwarf virus have kept it popular despite having been released 60 years ago. Mr. Waldo, as he is still referred to by his former technician John Martsching, was the consummate gentleman and gentle man. He was quiet and introverted and yet freely sent material everywhere. Waldo had a wry sense of humor. His bearded picture in Darrow's The Strawberry (1966) is how many people picture him. However, throughout his life he was only bearded for one year when, in celebration of Oregon's centennial, all men over the age of 25 were ordered to grow a beard or be fined. While Darrow's book came out about 10 years after the centennial, it is still the picture Waldo chose to submit. Apparently, several people reviewing the book thought that someone had mixed up the names and photos because those who knew Waldo did not recognize him with a beard. He was devoutly religious, even refusing to eat at restaurants that served beer, much to the chagrin of the then-starving Lawrence as they drove past restaurant after restaurant in this prefast food era. He spent much of his retirement serving the Gideon's ministry.

\section{GEORGE L. SLATE}

George Slate (1899-1976) (Fig. 2) was born in 1899 in Barnardston, Massachusetts and grew up on a dairy farm. He earned his BS from the University of Massachusetts in 1921 and an MA from Harvard University in 1926. He began his long career with the New York State Agricultural Experiment Station in Geneva in 1922 where he was responsible for small fruit breeding. He assisted in the preparation of The Small Fruits of New York, which is still an incredibly valuable (and beautiful) resource. Slate typified the classic curious horticulturist who reveled in diversity. While I am sure he was born with an interest in diversity, it is also notable that he married the daughter of Ernest Wilson (from Harvard University's Arnold Arboretum), who is one of the greats of the golden age of British and American plant collecting. So, while he released red, black, and 


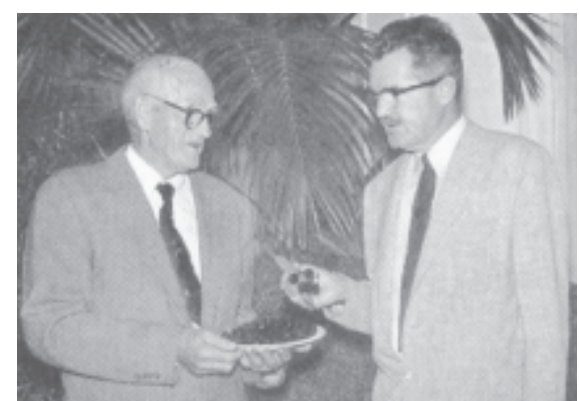

Fig. 2. George Darrow (left) and George Slate (right).

purple raspberry, blackberry, and strawberry cultivars, he also has a daylily and yew (Taxus sp.) named after him, was involved with nuts, and can be found repeatedly as a contributor to our knowledge of the minor fruit, such as pawpaw (Asimina sp.). His caneberry releases have had a dramatic commercial impact. His foresight in taking the character of primocane fruiting in raspberry and along with E.M. Meader (New Hampshire) developing elite germplasm that led to the release of 'Heritage' was novel. His 'Darrow' blackberry is still the cold hardy standard. However, he sold blackberries short when he told an audience that "there is no future in blackberry breeding because there is not enough variability." Several scientists feel that he was operating in a very narrow gene pool and therefore did not see the variability that others like those in Arkansas, Illinois, and Oregon were able to exploit. Personally, Slate was highly respected, modest, and very nice. He and Darrow were competitive with each other but still friends. When Darrow was announcing the release of 'Smoothstem' blackberry, Slate asked "George, don't you think they have awfully big seeds?" Darrow's responded without missing a beat "That's the way I like them. That way they don't get under my plate."

\section{CHESTER D. (CHET) SCHWARTZE}

Chester Schwartze (1902-1988) (Fig. 3) was born in 1902 in Yakima, Wash., to parents who ran a fruit orchard. He earned his BS in horticulture in 1924 and his $\mathrm{PhD}$ in 1935 from Washington State University. He took on the responsibilities for the strawberry and raspberry breeding program in 1932 . His caneberry

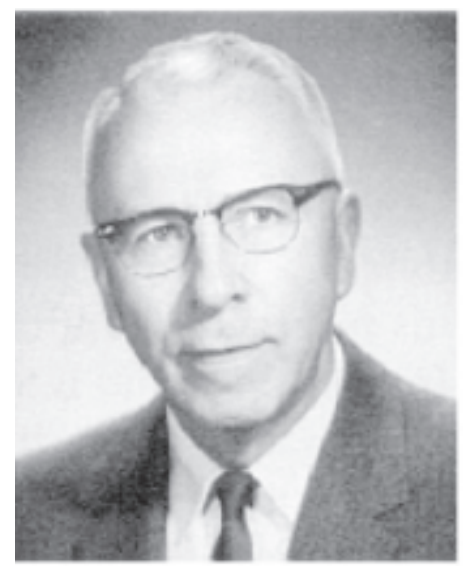

Fig. 3. Chester Schwartze. breeding emphasized developing raspberries that were suitable for processing and that were resistant to aphids and therefore the viruses they vectored. While his commercial strawberry cultivars were important for their time, especially 'Northwest', which accounted for $75 \%$ of Pacific Northwest production in the late 1960s (P. Moore, personal communication), and while 'Rainier' is still widely grown today, it was his release of 'Meeker' red raspberry that had profound impact on raspberry growing as it is one of the most widely grown cultivars in the world. Schwartze really liked raspberries and despite excellent work on strawberries and blueberries, raspberries were his passion. While he was known as being somewhat reserved and conservative, he was also considered outgoing and funny. He and Waldo with the USDA-ARS in Corvallis while cordial and generally cooperative had a lifelong competitiveness that led each to claim that the other "never sent their best plant material to me."

\section{FRANCIS J. (WHITEY) LAWRENCE}

Whitey Lawrence (Fig. 4) was born in 1925 in Towson Md. After serving in the U.S. Navy from 1942-1945, he earned his BS (1951), MS (1958), and PhD (1965) at the University of Maryland while working as an instructor and with I.C. Haut and F. Stark on everything from camellias to sweet potatoes along with berry crops. In 1965, he accepted the caneberry and strawberry breeding position with the USDA-ARS in Corvallis, Ore. Several of his strawberry, raspberry and blackberry cultivars had tremendous commercial impact. He had a particular interest in germplasm enhancement particularly disease resistance in all crops. Lawrence also placed a high value on flavor and this is evidenced by the success of 'Amity' raspberry which is neither large fruited nor extremely high yielding, but is widely grown because it is the best tasting primocane fruiting raspberry. While in his career he only released one thornless blackberry ('Waldo'), the extremely high quality thornless germplasm he created out of the 'Austin Thornless' background is in the process of returning dividends as several high quality, thornless cultivars for processing are now being released. Lawrence is a kind, soft spoken, but not shy, man who has willingly shared germplasm with many cooperators and helped create, with AgCanada and Washington State University,

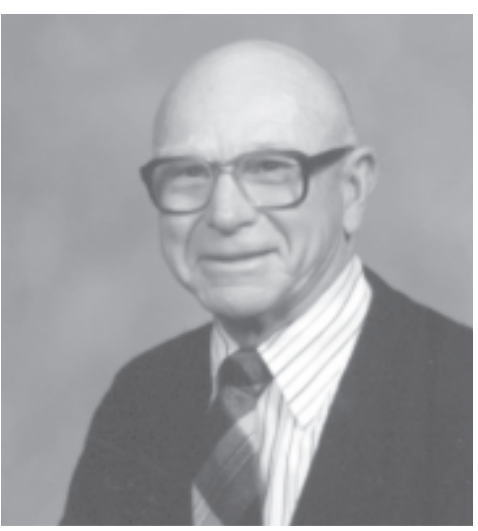

Fig. 4. Francis Lawrence. an incredibly cooperative group of breeding programs in the Pacific Northwest. Lawrence is $5 \mathrm{ft}$ tall, which only deserves mention because he had fun with his height. First, he claimed his height saved him from being killed by shrapnel in a bombing attack in World War II and later his good friendship with P. Breen at Oregon State University, who is very tall, created a lifetime of banter. While never called Whitey at home, he picked up this nickname while at the University of Maryland, apparently because he had a thick head of blonde hair. Lawrence is an athlete and has kept active jogging, golfing, biking, and playing squash and badminton well into his retirement.

\section{JOHN (JACK) W. HULL}

Jack Hull (1927-1976) (Fig. 5) was born in 1927 in Oklahoma City, Okla. He earned his BS from Oklahoma A \& M (1950) and his MS (1955) and $\mathrm{PhD}$ (1958) at the University of Maryland. His PhD thesis on blackberry chromosomes was considered by many to be a classic piece of work for the time. While his first professional position was as an Assistant Professor at the University of Arkansas, it was the position he began in 1963 with the USDA-ARS in Carbondale, Ill., where he had the greatest impact. In the 10 years, from the time he went to Carbondale until the station was closed in 1973 he developed some of the most important semi-erect blackberry germplasm and cultivars. 'Dirksen Thornless' and 'Black Satin' were his first releases. 'Hull Thornless' and 'Chester Thornless', while released by USDA-ARS Beltsville, were his selections that had been tested at Beltsville after the Carbondale stations closed. Between his $\mathrm{PhD}$ and 4 years in Arkansas, he must have developed a great feel for the germplasm that should be gathered and put to use as those who succeeded him at Arkansas and who knew the Carbondale station said that he did not take much plant material with him from Arkansas nor did he have much in place in Carbondale. Hull was described as being a gentle person whose life's ambition was to work with people and plants as individuals and not as crowds. Hull threw himself with intensity and enthusiasm into his work with great success. In reading and listening to descriptions about Jack or Wint as he was known by his family, he was

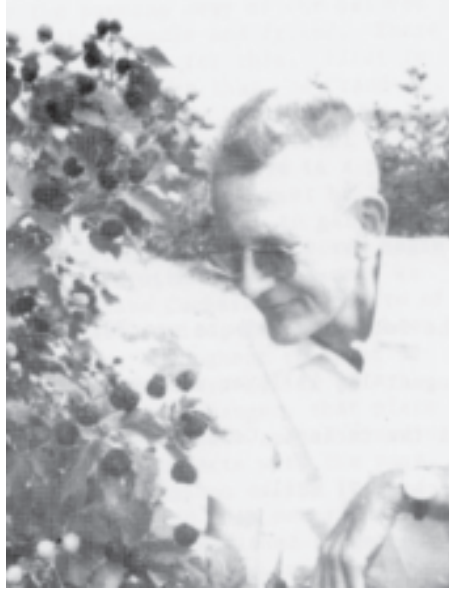

Fig. 5. Jack Hull. 
variously described as eccentric, troubled, and unusual. No one could come up with the perfect descriptor but it boiled down to him being driven, a bit eccentric, and prone to do things that were a bit unusual. His brother recalls phone conversations in the middle of the night where Jack could not contain his excitement at witnessing crossing-over in Rubus chromosomes. Others spoke of this same penchant for calling in the middle of the night to discuss achievements or challenges. Several colleagues throughout his career spoke of his willingness to throw himself into his work at the expense of his health and, unfortunately, he died young from cancer at only 49 years old.

\section{HUGH A. DAUBENY}

Hugh Duabeny (Fig. 6) was born in 1931 in Nanaimo, British Columbia. He earned his BSA in 1953 from the University of British Columbia and his PhD from Cornell in 1958. While offered breeding positions in the eastern U.S., he returned to his beloved British Columbia for a strawberry and raspberry breeding position with Agriculture and Agri-Foods Canada in Agassiz, British Columbia. He was successful in developing commercially successful strawberry and red raspberry cultivars and had longstanding interest and success in germplasm acquisition and incorporation. On the international scene, his fresh-market raspberries, particularly 'Tulameen', are very widely grown and the standards by which others are measured for fruit quality, particularly flavor. Daubeny is an extremely outgoing and gregarious person who used his friendships and interest in germplasm to bring together the best germplasm from many breeding programs. His well documented use of the East Malling and Scottish Crop Research Institutes germplasm as parents with his own material led to the development of a group of cultivars that are commercially important, widely adapted, and that have large, high quality fruit. His ability to bring people together has been instrumental in the success of the International Society for

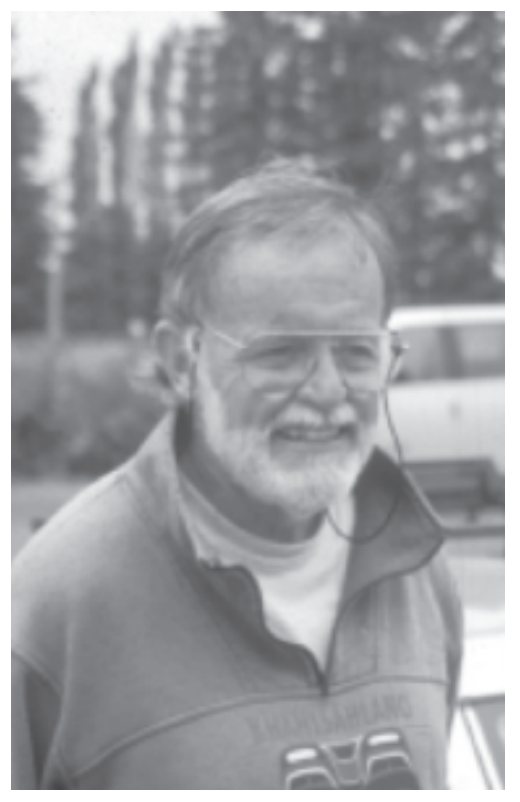

Fig. 6. Hugh Daubeny.
Horticultural Science (ISHS) International Rubus and Ribes Symposia. Similarly, he and Lawrence in Oregon and Schwartze and B. Barritt in Washington developed a true, fully cooperative effort that continues today with their successors. Daubeny is in many ways the classic, stereotypic professor. He is not only extremely interested in what everyone is doing and very inquisitive but also has a good dose of the absent-minded-professor syndrome which has charmed his colleagues for years. Some of his younger, less respectful colleagues, have retold the story many times of the wonderful ASHS presentation he gave while talking into the pointer and pointing with the microphone. His biggest problem early in his career at Agassiz were the "damn bears" in his plots. Daubeny has always been a champion of germplasm exchange, whether that meant obtaining wild material or exchanging with colleagues and he has decried the decrease in exchange that has come with the widespread patenting of cultivars. He is still actively championing germplasm and growing plants as he volunteers with the University of British Columbia Botanical Garden in Vancouver.

\section{JAMES N. MOORE}

Jim(Fig. 7) was born in 1931 in Vilonia, Ark. He earned his BSA in 1956 and MS in 1957 at the University of Arkansas and his $\mathrm{PhD}$ with Fred Hough at Rutgers University in 1961. His graduate program gave him two unexpected rewards. First, after loading up his belongings and wife to head to Rutgers, Hough told him to stop by Purdue University to visit a "fine young professor," Jules Janick, who had recently received a PhD from Purdue, thus beginning a lifelong friendship and successful collaboration. Second, when he arrived at Rutgers, Hough immediately left on a year-long sabbatical, leaving Moore and a non-English speaking, visiting scientist in charge of the strawberry breeding program. With hand signals and good eyes these two selected 'Raritan'. This experience trained him well to get his later program at Arkansas up and going quickly and gave him more confidence. His first position after graduation was Darrow's position with the USDA-ARS in Beltsville from 1961-1964. He was sent by Darrow or went with Darrow to visit far-flung test sites. He once had to sweet-talk the wife of a shotgun-toting New England farmer who really did not want to let them on his farm; she convinced her husband that he should let Moore get the USDA's plants. He jumped at the opportunity to return to Arkansas in 1964 where he remained for his career. Moore had a breadth of interest with active breeding programs in grapes, peach, strawberries, blueberries, and blackberries. Moore was a passionate breeder who had the ability to envision where a program needed to be in the future and then put together the people, funding, and ability to achieve his goals. This was not only to accomplish his goals but to also make sure a strong program was in place for his successors. He had the ability to invigorate the staff and the bosses and, as such, was one of the most respected faculty members at the University of Arkansas. The blackberry program has become one of the most highly regarded programs in the world and really did not exist when he arrived in 1964. By the 1970s, reliable commercial cultivars were released, by the late 1980s he had developed thornless cultivars, and, with John Clark, he laid the groundwork for the development of primocane fruiting cultivars that are in the release process. He was an innovator when it came to patenting. In the 1970s, his program was financially hurting so he sent donation solicitations out to everyone who might be impacted by the program. After receiving one donation of $\$ 25$ from a grower and later a note from Stark's Nursery thanking him for 'Cardinal' strawberry, which “made us $\$ 250,000$ ”, he decided to begin patenting. Despite his commanding presence, his graciousness, enthusiasm, genuine interest in what someone was doing, and positive nature have always drawn people to him whether for advice or a cold beer after a long day. Away from his work he was passionate about softball, pitching for and running the intramural team for years. While he no longer is playing softball, he continues his longstanding passion for gardening where he is particularly serious about his tomatoes.

Each of these scientists made major contributions in caneberry breeding. While they each had very distinct personalities they had a few things in common. They were generally considered to be kind and friendly men, which no doubt facilitated germplasm exchange. They were passionate about the crops they worked with; they were not the types to be interested in model crops that you could not eat. They loved fruit and the variability that they could observe in their fields. While breeding small fruit crops is a historically recent event, it is truly amazing what these scientists did with the development of blackberry and primocane fruiting raspberry cultivars that have been the cornerstones for the development of commercially successful industries.

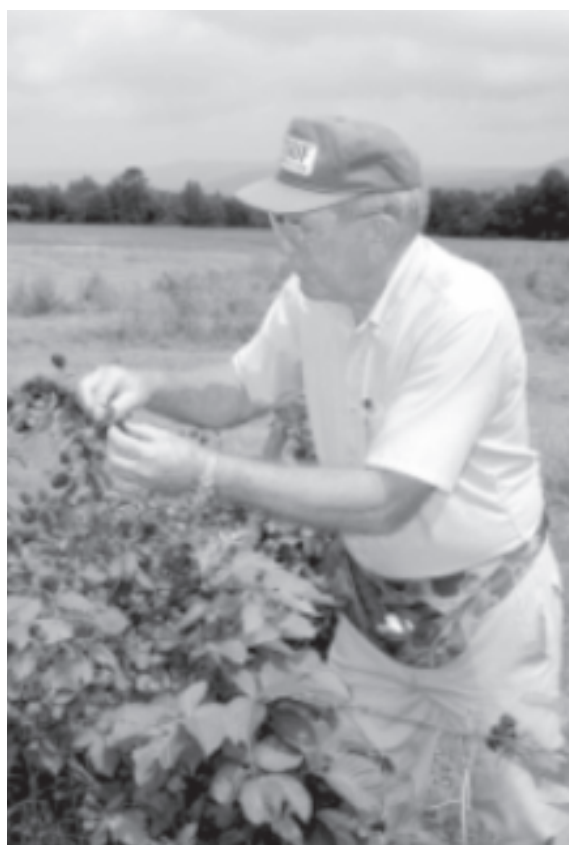

Fig. 7. Jim Moore. 